\title{
PROFIL BERPIKIR SISWA DALAM MEMECAHKAN MASALAH MATEMATIS BERDASARKAN MODEL POLYA
}

\author{
Ragil J. Purnomo*, Sri A. Widodo, Dafid S. Setiana \\ Universitas Sarjanawiyata TamansiswaYogyakarta \\ *purnomo0502@gmail.com
}

Dikirim: 02 Oktober 2019. Diterima: 23 Oktober 2019. Dipublikasikan: 31 Januari 2020

\begin{abstract}
ABSTRAK
Penelitian ini bertujuan untuk mengetahui proses berpikir yang dilakukan siswa dalam menyelesaikan masalah matematika berdasarkan perkembangan kognitif Piaget. Jenis penelitian ini adalah kualitatif deskriptif. Subjek penelitian ini adalah 4 siswa di SMP Negeri 15 Yogyakarta yang diambil secara purposivesampling. Teknik pengumpulan data menggunakan tes dan wawancara. Teknik analisis data yang digunakan adalah reduksi data, penyajian data, verifikasi data, dan penarikan Kesimpulan. Hasil penelitian menunjukan bahwa siswa kongkret melakukan proses berpikir asimilasi dalam memahami masalah (tahapan diketahui dan ditanyakan), melakukan proses berpikir akomodasi dalam melaksanakan rencana (tahapan dijawab), dan melakukan proses berpikir asimilasi dalam tahap memeriksa kembali (menyimpulkan hasil jawaban). Sedangkan pada siswa transisi melakukan proses berpikir berpikir asimilasi dalam memahami masalah (tahapan diketahui dan ditanyakan), melakaukan proses berpikir asimilasi dalam melaksanakan rencana (tahapan dijawab), dan melakukan proses berpikir asimilasi dalam tahap memeriksa kembali (menyimpulkan hasil jawaban).
\end{abstract}

Kata kunci:Pemecahan Masalah, Polya, Proses berpikir

\begin{abstract}
This study aims to observestudent's thinking process in solving mathematical problems based on Piaget cognitive development. This research belongs to descriptive qualitative. The subjects of this study were 4 students at SMP (Junior High School) Negeri 15 Yogyakarta taken by purposive sampling. Data collection techniques using tests and interviews. Data analysis techniques used are data reduction, data presentation, data verification, and drawing conclusions. The findings are students concretely did the assimilation thinking process in understanding the problem (known and asked stages), carried out the thought process of accommodation in carrying out the plan (the stages were answered), and carried out the assimilation thinking process in the re-checking stage (summarizing the results of the answers). While the transition students do the thinking process of thinking assimilation in understanding the problem (the stages are known and asked), doing the assimilation thinking process in carrying out the plan (the stages are answered), and doing the assimilation thinking process in the stage of checking back (producing the answer results).
\end{abstract}

Keywords: Thinking of process, problem solving, Polya

\section{Pendahuluan}

Pendidikan merupakan usaha sadar untuk menyiapkan peserta didik melalui kegiatan bimbingan, pengajaran, dan latihan bagi peranannya di masa yang akan datang. Sekolah sebagai suatu pendidikan formal, secara sistematis merencanakan bermacammacam lingkungan, yakni lingkungan pendidikan yang menyediakan berbagai kesempatan bagi peserta didik untuk melakukan berbagai kegiatan belajar. Dengan berbagai kesempatan belajar itu, pertumbuhan dan perkembangan peserta didik diarahkan dan didorong kearah pencapaian tujuan yang dicitacitakan. Lingkungan tersebut disusun dan ditata dalam suatu kurikulum, yang pada gilirannya dilaksanakan dalam bentuk proses pembelajaran (Oemar Hamalik, 2014).

Matematika merupakan mata pelajaran yang diajarkan disetiap jenjang pendidikan formal dan merupakan bagian dari mata pelajaran wajib dalam pendidikan nasional. Matematika memiliki peran yang sangat penting karena matematika adalah ilmu dasar yang digunakan secara luas dalam berbagai bidang kehidupan(Vandini, 2016; Sri Adi Widodo, 2011). Selain itu, kemampuan untuk memecahkan masalah dalam pembelajaran Matematika merupakan salah satu kemampuan yang harus dimiliki oleh peserta didik (BSNP, 2006; National of Council Teacher of Mathematics, 
2000). Hal ini sejalan dengan pendapat bahwa kemampuan memecahkan masalah merupakan salah satu tolok ukur kemampuan siswa dalam memahami konsep-konsep yang ada pada Matematika (Puadi \&Muhammad Irfan Habibie, 2018; Rismaati \& Komala, 2018; Sri Adi Widodo, 2012).Namun kenyataan dilapangan kemampuan memecahkan masalah matematis masih rendah, hal ini dapat dilihat dari hasil PISA beberapa tahun sebelumnya yang menunjukkan hasil yang belum memuaskan.

Hasil studi PISA tahun 2015, pada bidang matematika diperoleh skor 386, sedangkan pada tahun 2012 diperoleh dengan skor 375(Choridah, 2013; Nugrawati, Nuryakin,\& Afrillianto, 2018; Putri \& Zulkardi, 2018; Rismaratri \& Nuryadi, 2017; Wijayanti \& Retnawati, 2017). Walaupun ada peningkatan skor pada bidang Matematika dari tahun 2012 ke tahun 2015, tetapi peningkatan skor tersebut masih berada di bawah rata-rata internasional yaitu 490 (Istiandaru et al., 2018; Oktiningrum \& Hartono, 2016). Hasil studi TIMSS pada tahun 2015 (Rahmawati, 2017) mengungkapkan bahwa siswa Indonesia perlu penguatan kemampuan mengintegrasikan informasi, menarik simpulan, serta menggeneralisir pengetahuan yang dimiliki ke hal-hal yang lain dan hal ini dapat dilihat kesulitan siswa membuktikan matematika dengan jelas karena kurang memahami konsep dan aturan matematika(Bernard, Nurmala, Mariam, \& Rustyani, 2018; Pansa, Caswita, \& Suharsono, 2017; Rasnawati, Rahmawati, Akbar, \& Putra, 2019). Siswa Indonesia masih perlu dikembangkan lagi untuk kemampuan matematika tingkat tinggi, salah satu berpikir tingkat tinggi adalah kemampuan berpikir kreatif. Melalui pembelajaran matematika siswa diharapkan mampu mengembangkan kemampuan berfikir kreatif dan memiliki sikap ingin tahu terhadap matematika.

Salah cara yang dapat digunakan untuk memecahkan masalah matematis diantaranya adalah langkah memecahkan masalah dari Polya, yaitu memahami masalah, menyusun rencana, melaksanakan rencana, dan mengecek penyelesaian masalah(Polya, 1973). Hal ini sejalan dengan hasil penelitian sebelumnya yang menunjukkan bahwa metode pemecahan masalah Polya dapat memfasilitasi siswa agar terampil dalam pemecahan masalah(Sunarto, 2009; S A Widodo, Istiqomah, Leonard, Nayazik, \& Prahmana, 2019), penerapan pemecahan masalah Polya dapat meningkatkan hasil belajar siswa dalam menyelesaikan soal cerita(Marlina, 2013). Dengan menggunakan metode yang terstruktur dan sistematis seperti menggunakan metode dari Polya siswa menjadi lebih mudah dalam memahami konsep permasalahan yang dihadapi dan dapat dengan mudah menyelesaikan masalah matematika(Listiawan, 2016; Sri Adi Widodo \& Turmudi, 2017).

Selain kemampuan memecahkan masalah, fokus dalam pembelajaran matematika adalah menjelaskan proses berpikir siswa dalam memecahkan masalah matematis (Haryani, 2012; Lestari \& Wijayanti, 2013; Ngilawajan, 2013; Sopamena, 2017; Widyastuti, Usodo, \& Riyadi, 2013). Telah banyak penelitian terkait dengan proses berpikir siswa dalam memecahkan masalah seperti proses berpikir siswa berdasarkan gaya kognitif reflektif - impulsive(Aprilia, Sunardi, \& Trapsilasiwi, 2017; Hidayat, Sugiarto, \& Pramesti, 2013), hasil penelitian menunjukkan bahwa proses berpikir siswa gaya kognitif reflektif mengalami disequilibrium saat mengerjakan soal karena siswa belum pernah mengerjakan soal non rutin sebelumnya, siswa gaya kognitif reflektif selalu berpikir dahulu jika dihadapkan dengan masalah atau pertanyaan, dan siswa hanya menulis inti jawaban yang pokok saja saat mengerjakan tes pemecahan masalah(Aprilia et al., 2017). Dengan mengetahui proses berpikir siswa seperti pada proses berpikir siswa berdasarkan gaya kognitif, guru dapat dengan mudah menerka atau memprediksi alur berpikir siswa dalam memecahkan masalah.

Berdasarkan hal tersebut maka tujuan dalam penelitian ini adalah untuk mengetahui proses berpikir siswa dalam memecahkan masalah matematis pada materi segiempat. Siswa yang digunakan sebagai focus untuk mengetahui proses berpikir adalah siswa berdasarkan perkembangan kognitif. Seperti yang telah diketahui secara umum bahwa perkembangan kognitif setiap individu terdiri dari sensori-motorik, pra-operasional, operasional kongkrit dan operasional formal (Alhaddad, 2012; Nurgiyantoro, 2005; Ojose, 2008; Piaget, 2003).

\section{Metode Penelitian}

Sesuai dengan tujuan yang akan diungkap pada penelitian ini, maka jenis penelitian ini adalah deskriptif kualitatif. Subyek penelitian diambil secara purposive sampling yang dilakukan 
Ragil J. Purnomo, dkk.

pada siswa kelas VII di SMP Negeri 15 Yogyakarta. Adapun alasan digunakan untuk menentukan siswa yang digunakan sebagai subyek penelitian adalah (1) kemampuan komunikasi agar mampu mengungkapkan proses berpikir dan kesahalan yang dilakukan, (2) hasil tes memecahkan masalah masalah segiempat, (3) pertimbangan guru pengampu, dan (4) hasil tes perkembangan kognitif siswa.

Instrumen yang digunakan dalam penelitian ini adalah Tes of Logical Operations (TLO) dan Tes Pemecahan Masalah (TPM). TLO bertujuan untuk mengkonfirmasi perkembangan kognitif siswa (Mutammam \& Budiarto, 2013; S A Widodo et al., 2019; Sri Adi Widodo, Turmudi, \& Dahlan, 2019), tes ini mengacu pada indokator kemampuan klasifikasi, kemampuan seriasi, kemampuan berpikir logis, kemampuan kompensasi, kemampuan berpikir proporsional, kemampuan peluang dan kemampuan berpikir korelasi (Leongson \& Limjap, 2003). Tes pemecahan masalah matematis yang digunakan berdasarkan materi yang ada pada segitiga dan segiempat. Tes ini disusun berbentuk uraian sebanyak dua masalah seperti pada gambar 1. Teknik analisi data yang digunakan adalah reduksi data, penyajian data, verifikasi data, dan penarikan Kesimpulan (Miles, Huberman, \& Saldaña, 2013).

Tentukan panjang lintasan AEFC pada persegi panjang $\mathrm{ABCD}$ disamping, apabila panjang $\mathrm{AB}$ adalah $8 \mathrm{~cm}$ dan $\mathrm{BC}$ adalah $6 \mathrm{~cm}$.

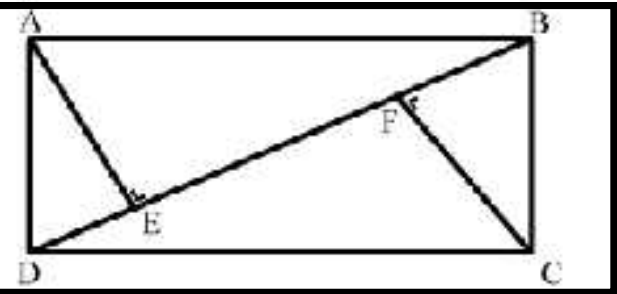

Gambar 1. Instrument tes pemecahan masalah matematis (soal no 2)

\section{Hasil Penelitian dan Pembahasan}

Sebelum siswa diungkap proses berpikir dalam memecahkan masalah matematis, terlebih siswa diberikan Tes Logical of Operational (TLO). Dari hasil tes TLO yang telah diberikan kepada siswa diperoleh bahwa 21 siswa $(32,81 \%)$ berada pada fase perkembangan kongkret, 43 siswa $(67,19 \%)$ berada pada fase perkembangan transisi dari kongkret menuju formal, dan tidak ditemukan siswa pada perkembangan formal. Berkaitan dengan hasil ini, maka subyek penelitian yang digunakan adalah 2 siswa pada perkembangan kongkret dan 2 siswa pada perkembangan transisi dari kongkret menuju formal.

Metode menyelesaikan masalah dari Polya ini, disesuaikan dengan karakteristik siswa di Indonesia menjadi Diketahui, Ditanyakan, Dijawab (Widodo \& Sujadi, ...). Pada tahap diketahui dan ditanyakan dari masalah yang dihadapi, merujuk pada langkah dari Polya, sedangkan pada tahapan dijawab, merujuk pada tahapan melaksanakan rencana untuk melaksanakan rencana untuk memecahkan masalah. Terkadang, siswa memberikan sebuah pernyataan konklu atau Kesimpulan di akhir proses menyelesaikan masalah. Langkah ini merujuk pada langkah memeriksa kembali dalam memecahkan masalah. Berkaitan dengan hal ini maka proses menyelesaikan masalah matematis menggunakan langkah langkah dari Polya yang telah diadaptasi atau disesuaikan dengan karakteristik siswa SMP di Indonesia.

\section{Memahami Masalah(Diketahui dan Ditanyakan)}

Seperti pada gambar 1 dapat dinyatakan bahwa subjek K1 dan K2 dapat menuliskan apa yang diketahui dan apa yang ditanyakan pada lembar jawaban, subjek K1 dan K2 mampu menuliskan apa yang diketahui dengan benar. Maka subjek K1 dan K2 memahami soal dengan melakukan proses berpikir asimilasi 

Ragil J. Purnomo, dkk.

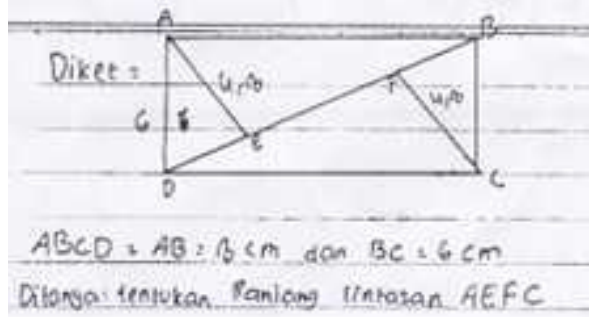

(a) jawaban subyek K1

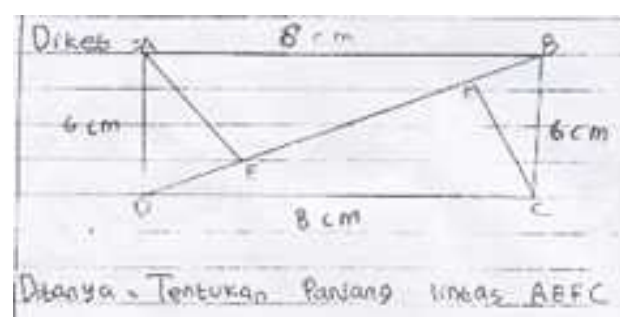

(b) jawaban subyek K2

Gambar 2. Jawaban subyek kongkret dalam memahami masalah

Seperti pada gambar 2 dapat dinyatakan bahwa subjek T1 dan T2 dapat menuliskan apa yang diketahui dan apa yang ditanyakan pada lembar jawaban, subjek T1 dan T2 mampu menuliskan apa yang diketahui dengan benar. Maka subjek T1 dan T2 memahami soal dengan melakukan proses berpikir asimilasi.

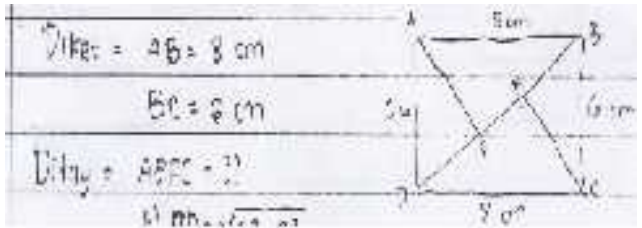

(a) jawaban subyek T1

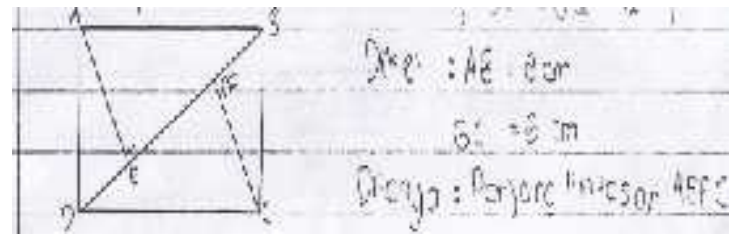

(b) jawaban subyek T2

Gambar 3. Jawaban subyek Transisi dalam memahami masalah

Di dalam pikiran seseorang ada struktur pengetahuan awal (skemata), dimana setiap skema berperan sebagai suatu filter dan fasilitator bagi pengalaman dan ide-ide baru sehingga skema dapat dikembangkan dan diubah dengan proses asimilasi atau akomodasi. Asimilasi, yaitu mengubah struktur informasi yang baru masuk ke memori jangka pendek agar sesuai dengan skema/skemata yang sudah ada dalam memori jangka panjang. Asimilasi merupakan proses dimana stimulus baru dari lingkungan diintegrasikan pada skema yang telah ada (Adi, Meter, \& Kristiantari, 2014; Syaodih, 1995). Asimilasi merupakan proses pengintegrasian secara langsung stimulus baru ke dalam skema yang telah ada (Irpan, 2010), asimilasi merupakan proses individu dalam mengadaptasikan dan mengorganisasikan diri dengan lingkungan atau tantangan baru sehingga pengertian peserta didik berkembang (Kusmayadi, Sujadi, \& Muhtarom, 2011). Asimilasi tidak menghasilkan perkembangan atau skemata, melainkan hanya menunjang pertumbuhan skemata (Syaodih, 1995).

\section{Melaksanakan Rencana untuk Menyelesaikan Masalah (Dijawab)}

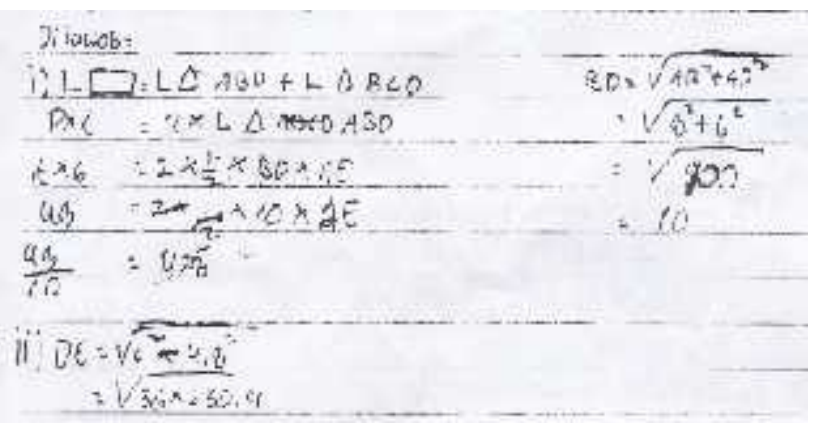

Gambar 4. Jawaban Siswa K1 dalam Melaksanakan Rencana

Untuk mengetahui proses berpikir subyek K1 dalam menyelesaikan masalah maka dilakukan wawancara sebagai berikut.

$\mathrm{P}$ : Coba jelaskan cara penyelesaiannya?

$\mathrm{K} 1$ : Salah gapapa ya pak, cuma ngarang ngerjainnya pak

$\mathrm{P} \quad$ : Iya gapapa, coba dijelaskan? 
Ragil J. Purnomo, dkk.

K1 : Pertama mencari BD dulu pak, BD sama dengan jumlah akar dari 8 kuadrat ditambah 6 kuadrat, terus ketemunya BD sama dengan 10, terus langkah selanjutnya luas persegi sama dengan luas segitiga $\mathrm{ABD}$ ditambah luas segitiga $\mathrm{ABD}$, terus 8 kali 6 sama dengan 2 kali setengah kali BD kali AE, 48 sama dengan 2 kali setengah 10 kali AE, 48 per 10 sama dengan $\mathrm{AE}$, terus $\mathrm{AE}$ sama dengan 4,8. Udah pak langkah selanjutnya sudah nggak paham.

$\mathrm{P} \quad$ : Nggak kamu coba teliti lagi jawabannya?

K1 : Nggak pak

Subjek K1 dapat melaksanakan rencana yang telah diobuat walaupun tidak lengkap pada lembar jawaban, subjek K1 mampu menjawab pertanyaan peneliti walaupun sedikit kebingungan dan kesulitan karena tidak paham terhadap soalnya. Sehingga dikatakan bahwa subjek K1 melakukan proses berpikir akomodasi. Subjek K1 juga menggunakan simbol dalam menyelesaikan masalah, maka subjek K1 juga melakukan proses berpikir abstraksi

Berdasarkan ringkasan wawancara, subjek K1 dapat menceritakan kembali pemahamannya pada soal nomor 2 walaupun belum benar dalam jawaban yang diberikan. Dengan demikian dapat disimpulkan bahwa subjek K1 melakukan proses berpikir akomodasi dan abstraksi dalam menyelesaikan masalah matematis.

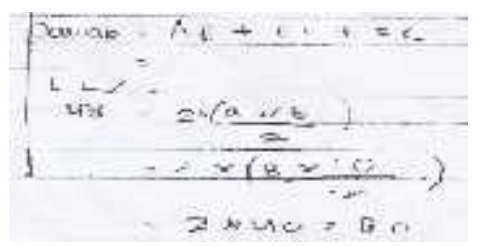

Gambar 5. Jawaban Siswa K2 dalam Melaksanakan Rencana

Untuk mengetahui proses berpikir subyek K2 dalam menyelesaikan masalah maka dilakukan wawancara sebagai berikut.

$\mathrm{P} \quad$ : Coba jelaskan cara penyelesaiannya?

K2 : Nggak bisa pak, itu aja cuma ngarang

$\mathrm{P} \quad$ : Kamu teliti lagi nggak jawabanmu?

K2 : Nggak pak.

Subjek K2 dapat menuliskan jawaban walaupun tidak lengkap pada lembar jawaban, subjek K2 tidak mampu menjawab pertanyaan peneliti dengan benar. Sehingga dapat dikatakan bahwa subjek K2 melakukan proses berpikir akomodasi. Berdasarkan ringkasan wawancara, subjek K2 tidak dapat menjelaskan pemahamannya. Dengan demikian dapat disimpulkan bahwa subjek $\mathrm{K} 2$ melakukan proses berpikir akomodasi dalam menyelesaikan masalah.

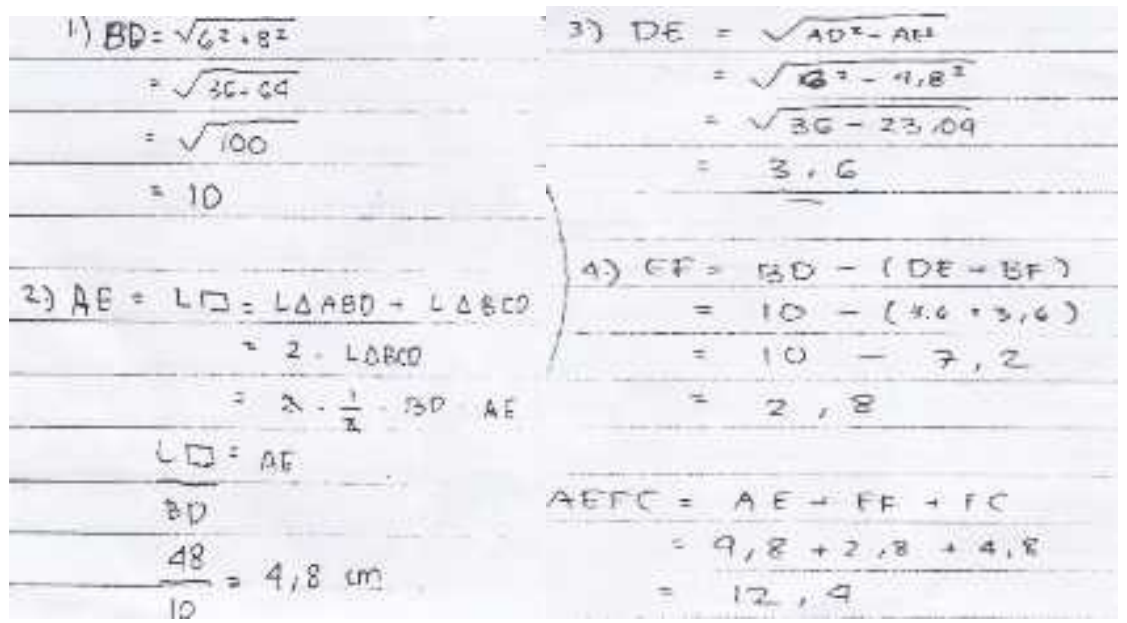

Gambar 6. Jawaban Siswa T1 dalam Melaksanakan Rencana

Ringkasan wawancara terhadap subjek T1 mengenai penyelesaian masalah matematis adalah sebagai berikut. 
Ragil J. Purnomo, dkk.

$\mathrm{P} \quad$ : Coba jelaskan cara penyelesaiannya?

T1 : BD sama dengan jumlah akar dari 6 kuadrat ditambah 8 kuadrat, BD sama dengan akar 100, $\mathrm{BD}=10$, langkah selanjutnya mencari $\mathrm{AE}$, luas persegi sama dengan luas segitiga $\mathrm{ABD}$ ditambah luas segitiga $\mathrm{BCD}$, sama dengan 2 kali luas segitiga $\mathrm{BCD}$, AE sama dengan 48 dibagi 10, AE ketemunya 4,8 cm, terus mencari DE dengan pytagoras, jumlah akar dari 6 kuadrat dikurangi 4,8 kuadrat sama dengan akar dari 36 dikurangi 23,04, DE sama dengan 3,6, EF sama dengan 10 dikurangi jumlah dari 3,6 ditambah 3,6, EF ketemunya 2,8, AEFC $=\mathrm{AE}+\mathrm{EF}+\mathrm{FC}, \mathrm{AEFC}=4,8+2,8+4,8, \mathrm{AEFC}=12,4$, jadi Panjang lintasan AEFC adalah $12,4 \mathrm{~cm}$

$\mathrm{P} \quad$ : Setelah selesai mengerjakan soal nomor 2, apakah kamu teliti lagi jawabannya?

T1 : Nggak pak

Subjek T1 dapat menuliskan jawaban dengan benar pada lembar jawaban, subjek T1 mampu menjawab pertanyaan peneliti dengan lancar. Sehingga dapat dikatakan bahwa subjek T1 melakukan proses berpikir asimilasi. Subjek T1 juga menggunakan simbol dalam menyelesaikan masalah, maka subjek T1 juga melakukan proses berpikir asimilasi. Berdasarkan ringkasan wawancara dan jawaban siswa T1 dapat menceritakan kembali pemahamannya dengan benar dan lancar. Dengan demikian dapat disimpulkan bahwa subjek T1 melakukan proses berpikir asimilasi dalam menyelesaikan masalah.

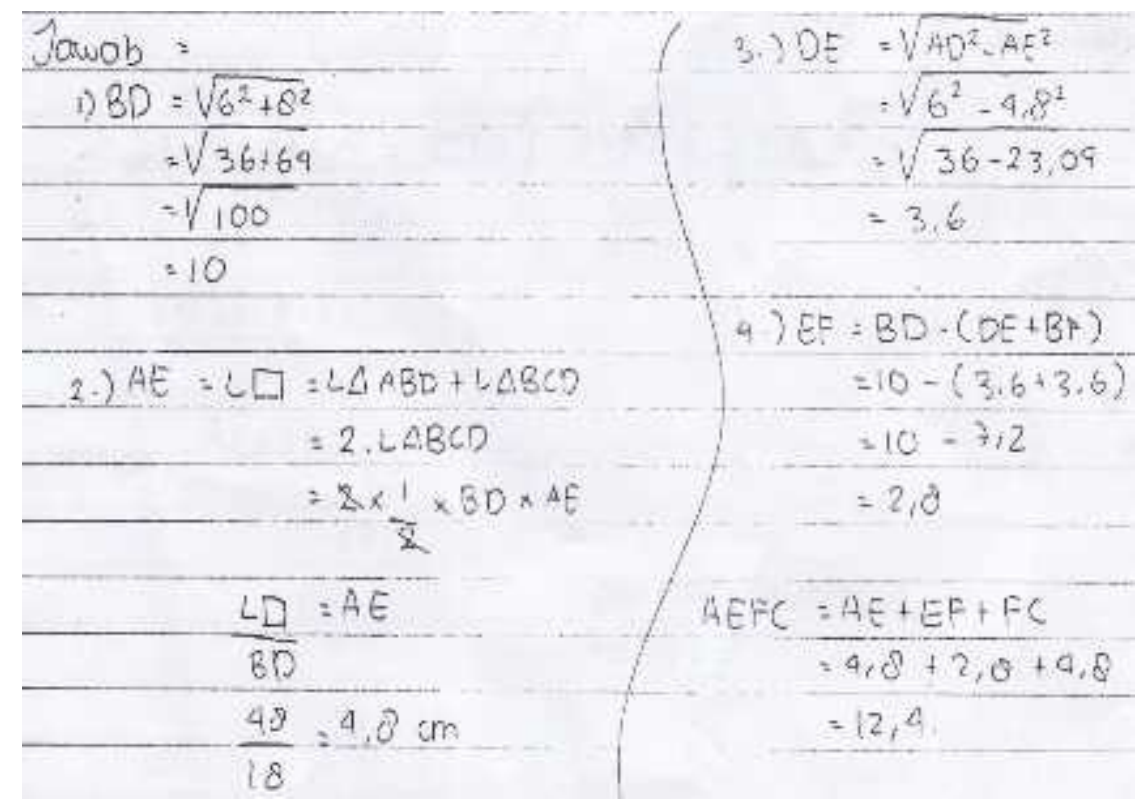

Gambar 7. Jawaban Siswa T2 dalam Melaksanakan Rencana

Ringkasan wawancara terhadap subjek T2 mengenai penyelesaian masalah matematis adalah sebagai berikut:

$\mathrm{P} \quad$ : Coba perhatikan soal nomor 2, coba jelaskan cara penyelesaiannya?

$\mathrm{T} 2$ : Langkah pertama mencari $\mathrm{BD}, \mathrm{BD}$ sama dengan jumlah akar dari 6 kuadrat ditambah 8 kuadrat, $\mathrm{BD}$ sama dengan akar $100, \mathrm{BD}=10$, langkah selanjutnya mencari $\mathrm{AE}$, luas persegi sama dengan luas segitiga ABD ditambah luas segitiga $\mathrm{BCD}$, sama dengan 2 kali luas segitiga $\mathrm{BCD}, \mathrm{AE}$ sama dengan 48 dibagi $10, \mathrm{AE}=4,8 \mathrm{~cm}$, langkah selanjutnya mencari $\mathrm{DE}$ dengan pytagoras, jumlah akar dari 6 kuadrat dikurangi 4,8 kuadrat sama dengan akar dari 36 dikurangi 23,04, $\mathrm{DE}=3,6 \mathrm{~cm}, \mathrm{EF}$ sama dengan 10 dikurangi jumlah dari 3,6 ditambah $3,6, \mathrm{EF}=2,8 \mathrm{~cm}, \mathrm{AEFC}=\mathrm{AE}+\mathrm{EF}+\mathrm{FC}, \mathrm{AEFC}=4,8+2,8+4,8, \mathrm{AEFC}=12,4 \mathrm{~cm}$, jadi panjang lintasan AEFC adalah 12,4 cm

$\mathrm{P}$ : Setelah selesai mengerjakan soal nomor 2, apakah kamu teliti lagi jawabannya?

T2 : Nggak pak 
Ragil J. Purnomo, dkk.

Subjek T2 dapat menuliskan jawaban soal nomor 2 dengan benar pada lembar jawaban, subjek T2 mampu menjawab pertanyaan peneliti dengan lancar. Sehingga dapat dikatakan bahwa subjek T2 melakukan proses berpikir asimilasi. Subjek T2 juga menggunakan simbol dalam menyelesaikan masalah, maka subjek T2 juga melakukan proses berpikir asimilasi. Berdasarkan ringkasan wawancara, subjek T2 dapat menceritakan kembali pemahamannya dengan benar dan lancar. Dengan demikian dapat disimpulkan bahwa subjek T2 melakukan proses berpikir asimilasi dalam menyelesaikan masalah.

\section{Tahap Menyimpulkan Proses Menyelesaikan Masalah}

Pada langkah terakhir dalam memecahkan masalah yakni menyimpulkan proses menyelesaikan masalah atau tahapan memeriksa kembali, keempat subyek (K1, K2, T1 dan T2) tidak menuliskan apapun pada lembar jawaban. Tetapi subyek sudah menyakini bahwa jawaban yang telah dituliskan tidak diperlukan untuk dilakukan proses pemeriksaan kembali jawaban. Berkaitan dengan hal ini maka seluruh subyek melakukan proses berpikir asimilasi.

\section{Simpulan}

Tahapan menyelesaikan masalah dari Polya yaitu memahami masalah, merencanakan untuk menyelesaikan masalah, melaksanakan rencana dan memeriksa kembali jawaban yang sudah dibuat. Tahapan menyelesaikan polya ini diadaptasi dan disesuaikan dengan karakteristik siswa sehingga tahapan memecahkan masalah menjadi tahapan diketahui, ditanyakan, dijawab, dan terkadap siswa melakukan tahap menyimpulkan proses menyelesaikan masalah. Dengan adaptasi langkah pemecahan masalah diperoleh bahwa siswa kongkret melakukan proses berpikir asimilasi dalam memahami masalah (tahapan diketahui dan ditanyakan), melakaukan proses berpikir akomodasi dalam melaksanakan rencana (tahapan dijawab), dan melakukan proses berpikir asimilasi dalam tahap memeriksa kembali (menyimpulkan hasil jawaban). Sedangkan pada siswa transisi melakukan proses berpikir berpikir asimilasi dalam memahami masalah (tahapan diketahui dan ditanyakan), melakaukan proses berpikir asimilasi dalam melaksanakan rencana (tahapan dijawab), dan melakukan proses berpikir asimilasi dalam tahap memeriksa kembali (menyimpulkan hasil jawaban).

\section{Daftar Pustaka}

Adi, I. M. S., Meter, I. G., \& Kristiantari, M. G. R. (2014). Pengaruh Model Pembelajaran Rme Berbantuan Media Semi Konkret Terhadap Hasil Belajar Matematika Siswa Kelas V SD Gugus 8 Kecamatan Gianyar, Kabupaten Gianyar Tahun Ajaran 2013/2014. Jurnal Mimbar PGSD Universitas Pendidikan Ganesha, 2(1), 1-11.

Alhaddad, I. (2012). Penerapan Teori Perkembangan Mental Piaget Pada Konsep Kekekalan Panjang. Jurnal Ilmiah Program Studi Matematika, 1(1), 31-44.

Aprilia, N. C., Sunardi, S., \& Trapsilasiwi, D. (2017). Proses Berpikir Siswa Gaya Kognitif Reflektif dan Impulsif dalam Memecahkan Masalah Matematika di Kelas VII SMPN 11 Jember. Jurnal Edukasi. https://doi.org/10.19184/jukasi.v2i3.6049

Bernard, M., Nurmala, N., Mariam, S., \& Rustyani, N. (2018). Analisis Kemampuan Pemecahan Masalah Matematis Siswa SMP Kelas IX pada Materi Bangun Datar. SJME (Supremum Journal of Mathematics Education), 2(2), 77-83.

BSNP. Peraturan Menteri Pendidikan Nasional Republik Indonesia No 22 Tahun 2006 Tentang Standar Isi Untuk Satuan Dasar dan Menengah (2006).

Choridah, D. T. (2013). Peran Pembelajaran Berbasis Masalah untuk Meningkatkan Kemampuan Komunikasi dan Berpikir Kreatif serta Disposisi Matematis Siswa SMA. Infinity Journal, 2(2), 1-9. https://doi.org/10.1016/j.jclinane.2016.06.009

Hamalik, Oemar. (2006). Proses Belajar Mengajar. Jakarta: PT Bumi Aksara

Haryani, D. (2012). Profil Proses Berpikir Kritis Siswa Sma Dengan Gaya Kognitif Field Independen Dan Berjenis Kelamin Perempuan Dalam Memecahkan Masalah 
Matematika. In Prosiding Seminar Nasional Matematika dan Pendidikan Matematika Pendidikan Matematika (pp. 978-979). Yogyakarta: Universitas Negeri Yogyakarta.

Hidayat, B. R., Sugiarto, B., \& Pramesti, G. (2013). Analisis Kesalahan Siswa Dalam

Menyelesaikan Soal Pada Materi Ruang Dimensi Tiga Ditinjau Dari Gaya Kognitif Siswa ((Penelitian dilakukan di SMA Negeri 7 Surakarta Kelas X Tahun Ajaran 2011/2012). Jurnal Pendidikan Matematika Solusi, 1(1), 39-46.

Irpan, S. (2010). Proses Terjadinya Kesalahan Dalam Penalaran Proporsional Berdasarkan

Kerangka Kerja Asimilasi Dan Akomodasi. Beta, 3(2), 100-117.

Istiandaru, A., Syakrina, N., Setyawan, F., Charitas, R., Prahmana, I., Sofyan, A., \& Hidayat, E. (2018). How Students Solves PISA Tasks : An Overview of Students ' Mathematical Literacy, 2(2), 129-138.

Kusmayadi, T. A., Sujadi, I., \& Muhtarom. (2011). proses Berpikir Siswa Kelas IX Sekolah Menengah Pertama Yang Berkemampuan Matematika Tinggi Dalam Memecahkan Masalah Matematika. JMEE, 1(2), 60-71.

Leongson, J. A., \& Limjap, A. A. (2003). Assessing The Mathematics Achievement of College Freshmen Using Piaget's Logical Operation. In The Hawaii international conference on education (pp. 1-25).

Lestari, S., \& Wijayanti, P. (2013). Proses Berpikir Kritis Siswa Dalam Memecahkan Masalah Matematika Open Ended Ditinjau Dari Kemampuan Matematika Siswa Dan Perbedaan Jenis Kelamin Pada Materi Kubus Dan Balok. Jurnal Matematika Atau Pembelajarannya, 3(2), 1-4.

Listiawan, T. (2016). PENGEMBANGAN LEARNING MANAGEMENT SYSTEM (LMS) DI PROGRAM STUDI PENDIDIKAN MATEMATIKA STKIP PGRI TULUNGAGUNG. JIPI (Jurnal Ilmiah Penelitian Dan Pembelajaran Informatika). https://doi.org/10.29100/jipi.v1i01.13

Marlina, M. (2013). Pengembangan Perangkat Pembelajaran Geometri SMP dengan Strategi Pembelajaran Kolaboratif Developing Geometry Learning Kits for Junior High Schools with Collaborative Learning Strategies. PYTHAGORAS: Jurnal Pendidikan Matematika, 8(2), 146-159.

Miles, M. B., Huberman, M. A., \& Saldaña, J. (2013). Qualitative Data Analysis. Los Angeles: Sage Publications.

Mutammam, M. B., \& Budiarto, M. T. (2013). Pemetaan Perkembangan Kognitif Siswa Menggunakan Tes Operasi Logis (TOL) Piaget Ditinjau Dari Jenis Kelamin. Mathedunesa, 2(2), 1-6.

National of Council Teacher of Mathematics. (2000). Principles and Standards For School Mathematics. Virginia: NCTM.

Ngilawajan, D. A. (2013). Proses Berpikir Siswa Sma Dalam Field Independent Dan Field Dependent. Pedagogia, 2(1), 71-83.

Nugrawati, U., Nuryakin, \& Afrillianto, M. (2018). Analisis Kesulitan Belajar Pada Kemampuan Komunikasi Matematis Siswa MTs Dengan Materi Segitiga Dan Segiempat. Indomath: Indonesia Mathematics Edcuation, 1(2), 63-68.

Nurgiyantoro, B. (2005). Tahapan Perkembangan Anak Dan Pemilihan Bacaan Sastra Anak. Cakrawala Pendidikan, 24(2), 197-216.

Ojose, B. (2008). Applying Piaget's Theory of Cognitive Development to Mathematics Instruction. The Mathematics Educators, 18(1), 26-30.

Oktiningrum, W., \& Hartono, Y. (2016). Developing PISA-Like Mathematics Task With Indonesia Natural And Cultural Heritage As Context To Assess Students , Mathematical Literacy. Journal on Mathematics Education (JME), 7(1), 1-8.

Pansa, H. E., Caswita, \& Suharsono. (2017). Pengembangan LKPD dengan Model Problem Based Learning untuk Meningkatkan Kemampuan Komunikasi Matematis 
Siswa. Jurnal Pendidikan Matematika Unila, 5(3).

Piaget, J. (2003). The Psychology of Intelligence. New York: Routledge.

Polya, G. (1973). How Solve It: A new Aspect of Mathematical Method. New Jersey: Princeton University Press.

Puadi, E. F. W., \& Muhammad Irfan Habibie. (2018). Implementasi PBL Berbantuan GSP Software Terhadap Peningkatan Kemampuan Pemecahan Masalah Matematik Siswa. Indomath: Indonesia Mathematics Edcuation, 1(1), 19-26.

Putri, R. I. I., \& Zulkardi. (2018). Noticing Students' Thinking and Quality of Interactivity During Mathematics Learning. In Advances in Social Science, Education and Humanities Research (Vol. 174, pp. 549-553).

Rasnawati, A., Rahmawati, W., Akbar, P., \& Putra, H. D. (2019). Analisis Kemampuan Berfikir Kreatif Matematis Siswa SMK Pada Materi Sistem Persamaan Linier Dua Variabel (SPLDV) Di Kota Cimahi. Jurnal Cendikia: Jurnal Pendidikan Matematika, 3(1), 164-177.

Rismaati, \& Komala, E. (2018). Penerapan Pendekatan Matematika Realistik Terhadap Kemampuan Pemecahan Masalah Matematis Siswa. Indomath: Indonesia Mathematics Edcuation, 1(2), 163-172.

Rismaratri, D., \& Nuryadi. (2017). Pengaruh Model Pembelajaran Quantum Dengan Pendekatan Realistic Mathematic Education (RME) Terhadap Kemampuan Berfikir Kreatif Dan Motivasi Belajar Matematika. Jurnal Edudaksi Matematika Dan Sains, 5(2), 70-76.

Sopamena, P. (2017). Karakteristik Proses Berpikir Mahasiswa Dalam Mengonstruksi Bukti Keterbagian. Jurnal Matematika Dan Pembelajaran, 5(2), 169-192.

Sunarto, M. . D. (2009). Karakteristik Proses Berpikir Siswa Dalam Mempelajari Matematika Berbasis Tipe Kepribadian. Prosiding Seminar Nasional, Pendidikan Dan Penerapan MIPA, Fakultas MIPA, Universitas Negeri Yogyakarta, 481-492.

Syaodih, E. (1995). Psikologi Perkembangan. Bandung: Universitas Pendidikan Indonesia. Vandini, I. (2016). Peran Kepercayaan Diri terhadap Prestasi Belajar Matematika Siswa. Formatif: Jurnal Ilmiah Pendidikan MIPA. https://doi.org/10.30998/formatif.v5i3.646

Widodo, S A, Istiqomah, Leonard, Nayazik, A., \& Prahmana, R. C. I. (2019). Formal student thinking in mathematical problem-solving. Journal of Physics: Conference Series, 1188, 012087.

Widodo, Sri Adi. (2011). Efektifitas Model Pembelajaran Team Accelerated Instruction Pada Siswa Kelas X SMK Tunas Harapan Tahun Pelajaran 2008-2009. In Prosiding Seminar Nasional Penelitian, Pendidikan dan Penerapan MIPA (pp. 1-6). Yogyakarta: FMIPA - Universitas Negeri Yogyakarta.

Widodo, Sri Adi. (2012). Proses Berpikir Mahasiswa Dalam Menyelesaikan Masalah Matematika Berdasarkan Dimensi Healer. In Prosiding Seminar Nasional Matematika dan Pendidikan Matematika (pp. 978-979).

Widodo, Sri Adi, \& Turmudi. (2017). Guardian Student Thinking Process in Resolving Issues Divergence. Journal of Education and Learning, 11(4), 431-437.

Widodo, Sri Adi, Turmudi, \& Dahlan, J. A. (2019). An Error Students In Mathematical Problems Solves Based On Cognitive Development. International Journal of Scientific \& Technology Research, 8(7), 433-439.

Widyastuti, R., Usodo, B., \& Riyadi. (2013). Proses Berpikir Siswa Smp Dalam Menyelesaikan Masalah Matematika Berdasarkan Langkah- Langkah Polya. Jurnal Pembelajaran Matematika, 1(3), 239-249.

Wijayanti, I. K., \& Retnawati, H. (2017). Pengembangan Bahan Ajar Dengan Pendekatan Kontekstual Model Pembelajaran Active Joyful Effective Learning Pada Materi Segiempat Dan Segitiga Kelas VII Untuk Meningkatkan. Jurnal Pendidikan 
Range: Jurnal Pendidikan Matematika Vol. 1 No. 2 Tahun 2020 ISSN :2685-2373 Ragil J. Purnomo, dkk.

Matematika Dan Sains, 6(7), 74-84. 